\title{
Beberapa Masalah \\ Muatan Materi UU No. 22 Tahun 1999 dan Implikasinya terhadap Otonomi Daerah dalam Kerangka Negara Kesatuan Republik Indonesia
}

\author{
Sudi Fahmi
}

\begin{abstract}
As a correction of local government regulation according to Law No. 51974 which is centralistic in nature, the advent of Law No. 221999 is expected to blow the wind of change in the substance and the paradigm of the real autonomy. That is, the mechanism of decentralization system which guarantees (respects) the existence of local government independence in regulating and arranging their home affairs and the dispersion of national revenue to local govemment for the even distribution of social justice. Nevertheless; the problems rises when the content of Law No 221999 runs against the amendment of the Constitution 45, especially conceming article 18, article 18A, and article 18B. Namely, the confusion of decentralization which is placed as "principle/basic" in the (autonomious) system of local govemment whereas in theory it is a "process". The second is related to article 8 (2) which gives privileges structurally to local govemment, while, on the other hand, it can endanger the integrity of NKRI. To review the substance of Law No 221999 is a wise step in offering solutions.
\end{abstract}

\section{Pendahuluan}

Sungguh sangat bijaksana konsensus yang dicapai para the founding fathers Indonesia, yaitu membangun persatuan dan kesatuan bangsa dalam bingkai negara kesatuan sebagai elemen perekatnya. Struktur geografis yang terhampar luas dengan kemajemukan masyarakatnya juga perlu diakomodasikan melalui desentralisasi. Sesuai Pasal 1 ayat (1)
UUD 1945 negara Indonesia adalah negara kesatuan dan kemudian dibangun pula berbagai daerah otonom melalui Pasal 18 UUD 1945 untuk memungkinkan terdapatnya kebijakan dan implementasi sesuai dengan kondisi riil masyarakat yang bersangkutan. ${ }^{1}$

Ketika proses reformasi terus bergulir gejola masyarakat yang menginginkan 
wilayahnya melepaskan diri terasa semakin menguat. Wilayah-wilayah tersebut di antaranya: Aceh, Riau, Irian Jaya, dan TimorTimur. ${ }^{2}$ Untuk meredam tuntutan ini muncul berbagai wacana dalam upaya memberikan solusi atas situasi politik kala itu. Wacana yang berkembang terbagi menjadi dua bagian. Pertama, mereka yang mengusulkan untuk dibentuk negara federal. Kedua, mereka mengusulkan tetap dalam konteks negara kesatuan, dengan memberikan otonomi yang seluas-luasnya ke daerah.

Akhirnya, masalah ini ditengahi dengan ditetapkannya UU No. 22 Tahun 1999 tentang Pemerintahan Daerah. ${ }^{3}$ UU No. 22 Tahun 1999 ditetapkan dengan maksud untuk tetap merekatkan bangsa Indonesia dalam kerangka Negara Kesatuan Republik Indonesia. Dalam praktiknya banyak problematika yang dihadapi baik di dataran yuridis normatif maupun dalam dataran teknis aplikasinya, sehingga kecenderungannya UU No. 22 Tahun 1999 hampir-hampir tidak dapat diimplementasikan.

Dalam konteks ini penulis ingin memetakan beberapa masalah yang berkenaan dengan muatan materi UU No. 22 Tahun 1999 dan implikasinya dalam mencapai tujuannya, yakni mempersatukan bangsa ini dalam kerangka negara kesatuan Rl.

\section{Beberapa Permasalahan Muatan Materi UU No. 22 Tahun 1999}

Dapat dikatakan hampir setiap orang baik dari kalangan akademisi hukum maupun pemerintahan daerah mensikapi kelahiran UU No. 22 Tahun 1999 dengan penuh rasa optimis. ${ }^{4}$ Hal ini menjadi sesuatu yang wajar tatkala pemahaman terhadap otonomi daerah hanya dilandaskan pada UU No. 22 Tahun 1999. Setidaknya dapat diuraikan bahwa UU No. 22 Tahun 1999 secara substansial telah mengalami perubahan paradigma, struktur kekuasaan di daerah dan kewenangan daerah.

Rejim Orde Baru menggunakan paradigma kekuasaan yang "satu terpusat dan seragam" dalam tiga wujud berikut. Pertama, sentraliasi kekuasaan pada Pusat, Eksekutif, dan Presiden merupakan prakondisi bagi stabilitas politik, sedangkan stabilitas merupakan condition $\sin$ qua non bagi kesuksesan pembangunan nasional. Kedua, pembentukan

'Para founding fathers merumuskan bentuk negara ini yang ada dalam pikiran mereka adalah Negara Moralis dan Integralis. Negara selalu dipandang sebagai aktor yang budiman dalam menegakan keadilan dan moralitas masyarakat. Dalam negara integralis, kepentingan individu harus disingkirkan karena bersifat partikuleristik, sedangkan kepentingan negara menpakan kebenaran karena mewakili kepentingan-kepentingan universalistik. Sarundajang. 2000. Arus Balik Kekuasaan Pusat ke Daerah. Jakarta: Pustaka Sinar Harapan. HIm. 5. Lihat juga Tim Lapera. 2000. Otonomi versus Negara. Yogyakarta: Lapera. Hilm. XI.

'Untuk Timor-Timur akhirnya lepas juga setelah melalui proses jajak pendapat. Peristiwa ini terjadi pada saat pemerintah B.J. Habibie sebagai Presiden RI.

${ }^{3}$ Selanjutnya UU No. 22 Tahun 1999 tentang Otonomi Daerah dalam tulisan ini disebut UU No. 22 Tahun 1999.

"Lihat Editorial Media Indonesia. "Bom Waktu Otonomi Daerah." 9 November 2000. http://www.otoda.orid/ artikel/artikel 11.htm. 
budaya nasional oleh negara sebagai pengganti budaya lokal (penyeragaman budaya) merupakan prakondisi bagi persatuan dan kesatuan, bangsa. Ketiga, sentralisasi redistribusi kekayaan nasional akan menjamin pemerataan dan keadilan sosial. ${ }^{5}$

Sebagai ganti dari paradigma lama ini diajukan suatu paradigma baru yang merupakan kebalikan dari paradigma lama tersebut. Pertama, pemisahan kekuasaan di antara legislatif, eksekutif dan yudikatif, dan desentralisasi kekuasaan kepada daerah otonom merupakan prakondisi penghormatan kepada budaya lokal baik dalam arti pengetahuan lokal (local knowledge) maupun kejeniusan lokal (local genius) tidak salah akan menjamin pluralisme budaya, tetapi juga mendorong integrasi nasional. Kedua, desentralisasi sumber pendapatan dan penggunaan pendapat nasional kepada daerah otonom lebih mampu menjamin pemerataan dan keadilan sosial..$^{6}$

Dari aspek struktur pemerintahan daerah secara tegas UU No. 22 Tahun 1999 telah memisahkan kekuasaan eksekutif di daerah derigan lembaga legislatif. Sebelumnya berdasarkan UU No. 5 Tahun 1974 lembaga legislatif daerah ini menyatu dengan kekuasaan eksekutif. Oleh karena itu, fungsi kontrol yang harus dijalankan tidak dapat dilaksanakan secara efektif, sementara setelah ada pemisahan berdasarkan UU No. 22 Tahun 1999 diharapkan akan menjadi kondisi sebaliknya.

Di balik perubahan substansial 'yang ada pada UU No. 22 Tahun 1999, ada beberapa hal yang menarik untuk dicermati. Beberapa hal tersebut meliputi asas yang dibèrläkukan dalam UUD 1945 dengan UU No. 22 Tahun 1999 tentang asas-asas pemerintahan daerát" dan hubungan antara pemerintahän 'baik' di' tingkat pusat dan daerah.

Dalam penyelenggaraan pemerintahán daerah aspek terpenting yang perlü diperhatikan adalah menyangkut asas-asas pemerintahan daerah. Asas-asas ini mémiliki fungsi agar penyelenggaraan pemerintähan daerah dapat berjalan dengan baik dan teratur. Sebelumnya dalam UU No. 5 Tahun 1974 mengenal tiga asas pemerintahan daerah, yakni asas desentralisasi, asas dekonsentrasi dan tugas pembantuan (medebewind).

Secara teoritik pengertian desentralisasi menurut Logemann adalah pemerintähpemerintah setempat ini dapat diberi kedudukan mandiri yang lepas, dengan keuangan sendiri, dengan anggarán pendapatan dan belanja sendiri, serta dinasdinas sendiri yang menggantikan (sebagian) dinas-dinas departemen. ${ }^{7}$ Rondinelli dan Cheema mengartikan desentralisasi adalah: ${ }^{8}$

${ }^{5}$ Ramlan Surbakti. "Otonomi Daerah Seluas-luasnya dan Faktor Pendukungnya." http://www.otda.or.id/ Artikel/Ramlan.htm. Lihat juga Syamsuddin Haris. "Paradigma Baru Otonomi Daerah." Jum'at 28 April 2000. $<$ Kliping (suratkabar).htm>

${ }^{6} /$ bid.

$\because$ aris.

${ }^{7}$ The Liang Gie. 1993. Pertumbuhan. Pemerintahan Daerah di Negara Republik Indonesia. Yogyakarta: Liberty. HIm. 37.

${ }^{8}$ Riant Nugroho D. 2000. Otonomi Daerah Desentralisasi Tanpa Revolusi. Jakarta: PT Elex.Média Komputindo. HIm. 41-42. 
...the transfer of planning decission making or administrative authority from the central government to its field organizations, local administrative units, semi autonomous and parastatal organization.

Desentralisasi juga dapat diartikan wewenang untuk mengatur dan mengurus urusan pemerintahan tidak semata-mata dilakukan oleh satuan-satuan pemerintahan yang rendah, baik dalam bentuk satuan teritorial maupun fungsional. Satuan-satuan pemerintahan yang lebih rendah diserahi dan dibiarkan mengatur dan mengurus sendiri sebagian urusan pemerintahan. ${ }^{9}$

Secara umum desentralisasi terbagi dua, yakni; desentralisasi kewilayahan dan desentralisasi fungsional. Desentralisasi kewilayahan berarti pelimpahan wewenang dari pemerintah pusat kepada wilayah di dalam negara. Desentralisasi fungsional berarti pelimpahan wewenang kepada organisasi fungsional (atau teknis) yang secara langsung berhubungan dengan masyarakat. ${ }^{10}$

Menurut Irwan Soejipto desentralisasi kewenangan itu dapat dilakukan oleh Pemerintah Pusat dalam beberapa bentuk yang meliputi:"

1. Desentralisasi teritorial, yaitu desentralisasi kewenangan yang dilakukan oleh pemerintah kepada suatu badan hukum (openbaar lichaan) seperti persekutuan yang berpemerintahan sendiri, yakni persekutuan untuk membina keseluruhan kepentingan yang saling berkaitan dari golongan-golongan penduduk biasanya terbatas dalam suatu wilayah tertentu yang mereka tinggal bersama.

2. Desentraliasi fungsional adalah ide untuk memisahkan suatu bagian tertentu dari fungsi pemerintah negara atau daerah untuk dibentuk yang dipercayakan penyelenggaraannya kepada suatu organ atau badan ahli yang khusus itu.

3. Desentralisasi administratif, yaitu pelimpahan kewenangan penguasa kepada pejabat bawahannya sendiri.

Kemudian dekonsentrasi ialah pelimpahan sebagian dari kewenangan pemerintah pusat pada alat-alat pemerintah pusat yang ada di daerah. Pada hakekatnya alat pemerintah pusat ini melaksanakan pemerintahan sentral di daerah-daerah dan berwenang mengambil keputusan sendiri sampai tingkat tertentu berdasarkan bertanggung jawab langsung kepada pemerintah pusat, yang memikul semua biaya dan tanggung jawab terakhir mengenai urusan-urusan dekonsentrasi ini. ${ }^{12}$ Bagir Manan menyatakan bahwa dekonsentrasi adalah mekanisme untuk menyelenggarakan urusan Pusat di Daerah.

9Philipus M Hadjon, dkk. 1993. Pengantar Hukum Administrasi Negara. Yogyakarta: Gajah Mada University Press. HIm. 112.

${ }^{10}$ Riant Nugroho D. Op. Cit. Him. 42.

"Irwan Soejito. 1990. Hubungan Pemerintah Pusat dan Pemerintah Daerah. Jakarta: Rineka Cipta. HIm. 30-35.

${ }^{12}$ Solly Lubis. 1983. Perkembangan Garis Politik dan Perundang-undangan Pemerintah Daerah. Bandung: alumni. HIm. 35. 
Sebagai penyelenggaraan urusan pemerintah pusat, dekonsentrasi semestinya tidak terpisah dari pengaturan mengenai susunan alat-alat kelengkapan pemerintah pusat. ${ }^{13}$

Sementara yang dimaksud. tugas pembantuan ialah tugas ikut melaksanakan urusan-urusan pemerintah pusat atau pemerintah lokal yang berhak mengatur dan mengurus rumah tangga tingkat atasannya. ${ }^{14}$ Perbedaan tugas pembantuan dengan tugas rumah tangga sendiri, di sini urusannya bukan menjadi urusan rumah tangga sendiri, tetapi merupakan urusan pemerintah pusat atau pemerintah atasannya. Kepada pemerintah lokal yang bersangkutan diminta untuk ikut membantu penyelenggaraannya saja. ${ }^{15}$

Dalam konteks UU No. 22 Tahun 1999 saja asas yang dipergunakannya pun sama dengan yang tertuang pada UU No. 5 Tahun 1974. Hal ini menjadi logis mengingat pembentukan UU No. 22 Tahun 1999 dibuat sebelum adanya amandemen terhadap Pasal 18 UUD 1945. Hal ini menjadi sangat serius ketika melihat fakta hukum yang ada sekarang. Pasal 18 UUD 1945 telah mengalami proses amandemen dengan dibuktikan munculnya Pasal 18, Pasal $18 \mathrm{~A}$, dan Pasal 18 B UUD 1945. Keseriusan ini ditampakan pada bunyi Pasal 18 ayat (2) UUD 1945 yang menyatakan bahwa pemerintahan daerah propinsi, daerah kabupaten, dan kota mengatur dan mengurus urusan pemerintah menurut asas otonomi dan tugas pembantuan.
- Penghilangan asas- desentralisasi dan dekonsentrasi menurut Bagir Manan dapat dirunut dari pengertian umum desentralisasi. Desentralisasi adalah setiap bentuk atau tin: dakan memancarkan kekuasaan atau wewenang dari suatu organisasi, jabatan atau pejabat. Dengan demikian, dekonsentrasi dalam pengertian umum dapat dipandang sebagai suatu bentuk desentralisasi, karena mengandung makna pemencaran kekuasaan. Dalam kaitan dengan pemerintah otonom desentralisasi hanya mencakup pemencaran kekuasaan di bidang otonom. Van Der Pot menggabarkan desentralisasi dengan menyebutkan bahwa tidak semua peraturan dan penyelenggaraan pemerintahan dilakukan dari pusat (sentral). Pelaksanaan pemerintahan dilakukan baik oleh pusat maupun berbagai badan otonom. Badan-badan otonom ini dibedakan antara desentralisasi berdasarkan teritorial (territoriale decentralisatie) dan desentralisasi fungsional (functioneele décentralisatie). Bentuk desentralisasi menurut Van der Pot dapat dibedakan antara otomon dan tugas pembantuan. ${ }^{16}$

Berdasarkan pengertian di atas, mensejajarkan desentralisasi dengan tugas pembantuan sebagai asas-asas yang terpisah, menimbulkan kerancuhan bahkan kekeliruan. Tugas pembantuan merupakan salah satu bentuk dari desentralisasi. Lebih lanjut, memperhatikan pengertian yang diberikan

${ }^{13}$ Bagir Manan. 1994. Hubungan antara Pusat dan Daerah Berdasarkan Asas Desentralisasi Menurut UUD 1945. Jakarta: Pustaka Sinar Harapan. HIm. 160.

${ }^{14} \mathrm{R}$. Joeniarto. 1992. Perkembangan Pemerintah Lokal. Jakarta: Bumi Aksara. HIm. 18.

${ }^{15} /$ bid. Hlm. 18. HIm.10.

${ }^{16}$ Bagir Manan. 2001. Menyongsong Fajar Otonomi Daerah. Yogyakarta: Pusat Studi Hukum FH UII. 
pada desentralisasi seperti dimuat baik dalam UU No. 5 Tahun 1974 maupun UU No. 22 Tahun 1999, ada pencampuradukan antara desentralisasi dan otonomi. Desentralisasi adalah otonomi, sedangkan desentralisasi tidak sama dengan otonomi. Otonomi hanyalah salah satu bentuk desentralisasi. Perlu pula ditegaskan, desentralisasi bukan asas melainkan suatu proses. Asas adalah otonomi dan tugas pembantuan. ${ }^{17}$

Sama halnya dengan desentralisasi. Dekonsentrasi bukan asas tetapi proses atau cara menyelenggarakan sesuatu. Dekonsentrasi adalah subsistem sentralisasi yaitu cara menyelenggarakan sistem sentralisasi. Dengan perkataan lain, dekonsentrasi adalah instrumen sentralisasi. Karena itu, sangat keliru kalau ditempatkan dalam sistematik pemerintahan daerah yang merupakan anti tesis dari sentralisasi. ${ }^{18}$

Dengan adanya bunyi Pasal 18 ayat (2) menunjukan bahwa dari segi asas pemerintahan daerah yang terkandung dalam Pasal 18 ayat (2) dengan UU No. 22 Tahun 1999 mengalami kerancuhan asas. Oleh karena itu, mengenai asas ini merupakan salah satu permasalahan yang fundamental yang ada dalam muatan materi UU No. 22 Tahun 1999 yang tidak sejalan dengan Pasal 18 ayat (2) UUD 1945 yang seharusnya mengacu pada UUD 1945.

Dari segi lainnya yang dianggap bermasalah dengan muatan materi adalah termaktub dalam Pasal 4 ayat (2) yang menyatakan bahwa daerah-daerah sebagaimana dimaksud pada ayat (1) masingmasing berdiri sendiri dan tidak mempunyai hubungan hierarki satu sama lain. Bunyi pasal ini secara normatif tidak menjadi persoalan, akan tetapi untuk kepentingan negara kesatuan hal ini akan menimbulkan sikap egoisme di kalangan pemerintah daerah baik itu di propinsi maupun di kabupaten. Dengan kehadiran pasal ini akan sangat sulit mengkoordinasikan setiap kebijakan yang dibuat oleh pemerintah daerah. Hal ini sangat potensial untuk memunculkan konflik.

Implikasi Masalah Muatan Materi UUNo. 22 Tahun 1999 terhadap Otonomi Daerah dalam Kerangka Negara Kesatuan RI

Istilah negara mengandung banyak pengertian. L.J. van Apeldoorn mengatakan, negara dapat diartikan penguasa untuk menyatakan orang atau orang-orang yang melakukan kekuasaan tertinggi atas persekutuan rakyat yang bertempat tinggal dalam sesuatu daerah. Negara juga terkadang memiliki arti persekutuan rakyat, yakni untuk menyatakan sesuatu bangsa yang hidup dalam suatu daerah, di bawah kekuasaan yang tertinggi, menurut kaidah-kaidah hukum yang sama. Dalam arti lain negara mengandung sesuatu wilayah tertentu, dalam hal ini istilah negara dipakai untuk menyatakan sesuatu daerah di dalamnya diam sesuatu bangsa di bawah kekuasaan tertinggi. ${ }^{19}$

Di sisi lain Hans Kelsen menyatakan negara adalah persekutuan susunan zwangsordning, yaitu yang dipertahankan oleh paksaan yang

\section{Ibid.}

${ }^{18}$ Ibid.

${ }^{19}$ C.S.T. Kansil. 1986. Hukum Tata Negara Republik Indonesia. Jakarta: Bina Aksara. HIm. 4-5. 
mengandung hak memerintah dan terdapat kewajiban manusia untuk seharușnya mentaati perintahnya itu. Negara sama atau identik dengan hukum, sebab ketertiban negara merupakan personifikasi dari ketertiban hukum. ${ }^{20}$ Dari aneka ragam pengertian negara, maka pengertian yang terakhir merupakan pengertian yang dapat digunakan dalam materi tulisan ini.

Secara teoritis negara dapat digolongkan ke dalam dua bentuk. Bentuk negara itu adalah negara federasi dan negara kesatuan. Selain dua bentuk negara ini, dikenal bentuk lainnya yang disebut negara konfederasi. Menurut Jimiy Asshidiqie, negara konfederasi adalah negara yang memiliki konstitusi sendiri-sendiri, tetapi bersepakat untuk bergabung dalam perhimpunan longgar yang didirikan bersamasama dengan nama konfederasi. Dalam konfederasi kedaulatan terletak di negaranegara bagian. Keputusan pemerintah federal mengikat warganegara, tetapi keputusan pemerintah konfederasi tidak. ${ }^{21^{2}}$

Bentuk negara konfederasi merupakan gabungan negara-negara yang telah berdaulat dengan mempergunakan satu-satunya perangkat yang dimiliki, yaitu kongres. Artinya, negara-negara dalam konfederasi itu tetapi memiliki kedaulatan dan konstitusinya sendirisendiri (tidak ada pelimpahan wewenang), namun pemerintahan yang berdaulat di tiap negara itu bersepakat untuk duduk satu meja memikirkan segala sesuatu kemungkinan kerja sama dalam forum yang dinamakan, kongres tersebut. ${ }^{22}$

Negara federasi adalah negara yang. tersusun, daripada beberapa negara, mengadakan ikatan kerja sama yang eféktifi, tetapi di samping itu, negara-negara tersebut: masih ingin mempunyai wewenang-wewenang yang dapat diurus sendiri. Di dalam negara federasi ada dua macam pemerintahan, yaitu; Pertama, pemerintah federal. Ini adalah yang, merupakan pemerintahan gabungannya, atau pemerintahan ikatannya, atau pemerintahan": pusatnya. Kedua, pemerintah negara bagian. . Jadi, negara-negara itu yang semula berdiri. sendiri, di dalam negara federasi tersebut bergabung menjadi satu ikatan, dengan, maksud untuk mengadakan kerja sama antara; negara-negara tersebut demi kepentingan. mereka bersama, dan di samping itu masih ada kebebasan hak-hak kenegaraan daripada negara-negara bagian itu sendiri.3

Negara kesatuan (unitaris) adalah suatu negara yang merdeka dan berdaulat di mana di seluruh negara yang berkuasa hanyalah satu, pemerintah (Pusat) yang mengatur seluruh daerah. ${ }^{24}$ Berdasarkan pada pengertian inj maka bentuk. negara kesatuan sangat berlainan dengan bentuk negara federasi. Negara kesatuan tidak tersusun daripada

${ }^{20}$ Sjachran Basah. 1994. Ilmu Negara Pengantar, Metode dan Sejarah Perkembangan. Bandung: Citra Aditya. Him. 159.

Yobe

${ }^{21}$ Al Chaidar. et.al. "Federalisme Beberapa Tinjauan Teoritis." Edi Riyanto. et. al. (ed) dalam Federasi dan Disintegrasi. Ttp: Madani Press. HIm. 61.

${ }^{22}$ Ibid

${ }^{23}$ Soehino. 1996. Ilmu Negara. Yogyakarta: Liberty. HIm. 225.

${ }^{24}$ C.S.T. Kansil.'1983. Sistem Pemerintahan Indonesia. Jakarta: Aksara Baru. HIm. 4. 
beberapa negara dan bersifat tunggal, untuk wewenang tertinggi berada di pemerintahan pusat. C.F. Strong mengatakan bahwa a unitary state is one in which we find the habitual exercise of suprime legislative authority by one central power... (negara kesatuan adalah bentuk negara di mana wewenang legislatif tertinggi dipusatkan dalam suatu badan legislatif pusat). ${ }^{25}$

Pemerintah pusat mempunyai wewenang untuk menyerahkan sebagian kekuasaannya kepada daerah berdasarkan hak otonom, tetapi pada tahap akhir kekuasaan tertinggi tetap pada pemerintah pusat. Jadi kedaulatannya, baik kedaulatan ke dalam maupun ke luar, sepenuhnya terletak pada pemerintah pusat. Dengan demikian, yang menjadi hakekat negara kesatuan ialah bahwa kedaulatannya tidak tèrbagi, atau dengan perkataan lain, kekuasaan pemerintahan pusat tidak dibatasi, oleh karena konstitusi negara kesatuan tidak mengakui badan legislatif lain, selain badan legislatif pusat. Jadi, adanya kewenangan untuk membuat peraturan bagi daerahnya sendiri itu tidak berarti bahwa pémerintah daerah itu berdaulat, sebab pengawasan dan kekuasaan tertinggi tetap pada pemerintah pusat. ${ }^{26}$

C.F. Strong menyimpulkan bahwa ada dua ciri mutlak yang melekat pada negara kesatuan, yaitu; Pertama adanya supremasi dari Dewan Perwakilan Rakyat Pusat. Kedua, tidak adanya badan-badan lain yang berdaulat. Dengan demikian, bagi para warga negara dalam negara kesatuan itu hanya terasa adanya satu pemerintahan saja. ${ }^{27}$

Abu Daud Busroh menyatakan bahwa negara kesatuan adalah negara yang tidak tersusun dari beberapa negara, seperti halnya negara federasi, melainkan negara itu sifatnya tunggal; artinya, hanya ada satu negara, tidak ada negara dalam negara. ${ }^{28}$ Dengan demikian, di dalam negara kesatuan itu hanya ada satu pemerintahan pusat yang mempunyai kekuasaan atau wewenang tertinggi dalam segala lapangan pemerintahan.

Derivasi dari negara kesatuan ada yang menganut sistem sentralisasi. Maksudnya segala sesuatu dalam negara langsung diatur dan diurus oleh Pemerintah Pusat dan daerahdaerah hanya tinggal melaksanakan segala apa yang telah diperintahkan oleh Pusat. Di lain pihak ada juga negara kesatuan yang menganut sistem desentralisasi. Artinya kepada daerah-daerah diberi kesempatan dan kekuasaan untuk mengatur dan mengurus rumah tangga sendiri (otonomi daerah) yang dinamakan daerah otonom. ${ }^{29}$

Di Perancis dan Italia, penyelenggaraan pemerintahan di daerah secara ketat diawasi

${ }^{25}$ C.F. Strong. 1966. Modern Political Constitution. London: The English Language Book Society and Sidgwick \& Jackson Limited. HIm. 80.

${ }^{26}$ Meriam Budiardjo. 1988. Dasar-dasar Ilmu Politik. Jakarta: Gramedia. HIm. 140.

${ }^{27} \mathrm{bid}$.

${ }^{28}$ Abu Daud Busroh. 1993. Ilmu Negara. Jakarta: Bumi Aksara. Hlm. 64-65.

${ }^{29}$ Sri Soemantri. 1981. Pengantar Perbandingan Hukum Tata Negara. Jakarta: Rajawali. HIm. 52. Lihat juga C.S.T. Kansil. Op. Cit. HIm. 52. Lihatjuga Dann Sugandhi. 1981. Masalah Otonomi dan Hubungan antara Pemerintah Pusat dan Daerah di Indonesia. Bandung: Sinar Baru. Hlm.2. 
oleh agen-agen Pemerintah Pusat yang dikenal dengan sebutan prefect. Sementara urusan-urusan mengenai pendidikan, peradilan, pekerjaan umum (PU); pemungutan pajak-pajak, penyelenggaraan kepolisian, semua dilaksanakan oleh instansi-instansi pemerintah pusat, atas dasar ketentuan perundang-undangan yang dibuat secara terpusat, demi terciptanya keseragaman bagi seluruh negeri..$^{30}$

Negara kesatuan, terutama di negeri yang tidak bersifat Kontinental (dalam arti tidak satu daratan), telah menampakan beberapa keuntungan: ${ }^{31}$

1. Menghilangkan duplikasi kegiatan antara yang dilaksanakan pemerintah pusat dan daerah.

2. Menghindari kemungkinan timbulnya konflik antara berbagai tindakan daerah satu dan lainnya yang tidak sama kemampuannya menigingat semua daerah merupakan satu kebulatan wilayah.

3. Memungkinkan dalam mengajukan keseragaman dalam penerapan hukum dan penyelenggaraannya.

4. Memudahkan dalam mengajukan perubahan bilamana ada masalahmasalah baru yang menuntut adanya perbedaan penyelenggaraan administratif.

5. Di dalam negara demokrási, negara kesatuan tidak membatasi atau menghalangi kepentingan daerah untuk mempengaruhi penguasapenguasa pusat; jika sistem politiknya cukup memiliki, tingkat difusi kekuasaan yang tinggi, kepentingankepentingan daerah dapat dikembangkan atau dilindungi, melalui interaksi yang ditujukan kepada pemerintah pusat.

Sistem negara kesatuan juga ada kerugian-kerugian yang mungkin dialami. Organisasi dari negara kesatuan dapat saja menjadi pemerintah pusat sebagai pusat pemerintahan yang bersifat sentralistis. $\mathrm{Di}$ samping itu pemerintahan terpusat cenderung menetapkan keputusan-keputusan yang kurang memperhatikan aspirasi dan kebutuhan daerah. ${ }^{32}$

Setelah mengetahui bentuk negara dan mengkhususkan diri pada masalah bentuk negara kesatuan, maka dari teori umum ini dapat diperjelas lagi dengan melihat dalam konteks Indonesia. Berangkat dari UUD 1945 baik dalam Pembukaan maupun dalam Batang Tubuhnya Pasal 1 ayat (1) tidak ménunjukkan adanya persamaan pengertian dalam menggunakan istilah bentuk negara. Pembukaan menyatakan:

“..., maka disusunlah kemerdekaan kebangsaan Indonesia itu dalam suatu Undang-Undang Dasar Negara Indonesia yang terbentuk dalam susunan NegaraRepublik Indonesia yang berkedaulatan rakyat dengan berdasar kepada..."

${ }^{30}$ Syaukani HR. Menatap Harapan Masa Depan Otonomi Daerah. Kutai: Gerbang Dayaku.HIm. 65. ${ }^{31} /$ bid.

${ }^{32}$ lbid. 
Selanjutnya dalam Pasal 1 ayat (1) UUD 1945 dirumuskan sebagai berikut bahwa Negara Indonesia adalah negara kesatuan yang berbentuk republik. Dari dua ketentuan di atas, orang tidak dapat mengetahui dengan tepat apakah penggunaan istilah bentuk negara itu ditujukan kepada sifat negara Indonesia sebagai Republik ataukah sebagai Negara Kesatuan. ${ }^{33}$

Sebenarnya dari bunyi Pasal 1 ayat (1) UUD 1945 dapat ditarik kesimpulan bahwa pada dasarnya negara Indonesia adalah negara kesatuan yang didasarkan pada sistem desentralisasi. Dalam hal ini Pemerintah Pusat yang menentukan wewenang apa saja yang akan diberikan kepada pemerintah di daerah berdasarkan asas-asas pemerintahan daerah. Lebih dari itu bentuk penentuan wewenang ini biasanya diatur dalam perundangundangan, di luar itu maka daerah tidak diberi kewenangan.

Untuk Indonesia dalam tinjauan historis sudah banyak peraturan perundangundangan yang mengatur tentang bagaimana menentukan kewenangan dari pusat ke daerah. Terakhir pengaturan masalah ini adalah dengan ditetapkannya UU No. 22 Tahun 1999 tentang Pemerintahan Daerah. Kehadiran UU No. 22 Tahun 1999 merupakan perwujudan atas aspirasi yang berkembang di masyarakat. Di mana pada masa sebelumnya masalah pengaturan kewenangan daerah ini diatur dalam UU No. 5 Tahun 1975.

Oleh karena UU No. 5 Tahun 1975 yang sebelumnya ini dianggap telah melahirkan sistem pemerintahan sentralistik, maka masyarakat menuntut untuk diformulasikan perundang-undangan yang baru dengan memberikan kewenangan ke daerah yang lebih besar. Bahkan tuntutan masyarakat ini tidak sebatas sampai di sini yang lebih ekstrim lagi mereka pun menuntut untuk melepaskan diri dari negara kesatuan republik Indonesia, akibat trauma politik yang telah dialami di masa rejim Orde Baru.

Akhirnya pemerintah menetapkan UU No. 22 Tahun 1999. Dalam UU No. 22 Tahun 1999 kalau mencermati dari kewenangannya, maka undang-undang ini memberi kewenangan yang sangat besar kepada daerah. Pada awalnya banyak pihak yang merespon secara positif atas kehadiran UU No. 22 Tahun 1999 bahkan. mereka mendorong untuk segera diimplementasikannya undang-undang ini.

Dalam kenyataannya ternyata dalam mengimplementasikan UU No. 22 Tahun 1999 mengalami berbagai macam permasalahan. Permasalahan yang dimaksud seperti yang telah diungkapkan di atas. Hal yang utama untuk diungkap bahwa ternyata dengan permasalahan itu implikasinya tidak hanya. kepada proses implementasi otonomi daerah, tetapi juga sangat berpengaruh kepada keutuhan Negara Kesatuan Republik Indonesia.

Dengan adanya asas pemerintahan daerah. yang tidak sama antara apa yang termuat dalam konstitusi maupun UU No. 22 Tahun 1999, maka tak pelak lagi akan melahirkan sejumlah permasalahan. Perlu diingat bahwa asas ini merupakan fundamen bagi terlaksananya sistem otonomi daerah secara keseluruhan.

${ }^{33}$ Moh. Kusnardi dan Harmaily Ibrahim. 1981. Hukum Tata Negara Indonesia. Jakarta: Pusat Studi Hukum Tata Negara FHUI dan CV. Sinar Bakti. HIm. 165. 
Di sisi lain dengan dinyatakannya secara gas bahwa UU No. 22 Tahun 1999 mengakui Jak adanya hubungan antara propinsi dan abupaten secara hirarkis. Fakta ini 'engindikasikan bahwa tidak ada konsistensi ari para pembuat undang-undang dengan onsepsi negara kesatuan Republik idonesia. Sehingga akan sangat sulit ntuk menjaga sistem negara kesatuan engan model seperti ini, sebab secara teoritis sbenarnya sistem negara kesatuạn dengan 'stem desentralisasi tidaklah diartikan semotong sistem koordinasi. Kalau koordinasi ntara propinsi dan daerah, maka irtanyaannya siapa yang akan mengontrol zerah secara makro dalam konteks Negara esatuan Republik Indonesia? Tidakah ini kan menjadi potensi bagi disintegrasi angsa?

\section{impulan}

Secara umum UU No. 22 Tahun 1999 dari egi muatan materi perundang-undangan ıdah dianggap cukup baik bagi kepentingan rasyarakat secara keseluruhan. Akan tetapi U. No. 22 Tahun 1999 ini masih diperlukan embaharuan-pembaharuan dalam beberapa' agian muatan materi, yaitu dalam masalah sas pemerintahan daerah yang perlu isinkronisasikan dengan Pasal 18 ayat (2) UD 1945, serta merubah isi Pasal 4 atau (2). 'U No. 22 Tahun 1999 yang menyatakan ahwa propinsi dan kabupaten tidak ada ubungan hirarkis. $\square$

\section{Jaftar Pustaka}

:asah, Sjachran. 1994. Ilmu Negara Pengantar, Metode dan Sejarah Perkembangan. Bandung: Citra Aditya.
Budiardjo, Meriam. 1988. Dasar-dasar IImu Politik. Jakarta: Gramedia.

Busroh, Abu Daud. 1993. IImu Negara. Jakarta: Bumi Aksara.

D, Riant Nugroho. 2000. Otonomi Daerah Desentralisasi Tanpa Revolusi. Jakarta: PT Elex Media Komputindo.

Edi Riyanto. et. al. (ed). Federasi dan Disintegrasi. Ttp: Madani Press.

Hadjon, Philipus M dkk. 1993. Pengantar Hukum Administrasi Negara. Yogyakarta: Gajah Mada University Press.

Haris, Syamsuddin.."Paradigma Baru Otonomi Daerah." Jum'at 28 April 2000. Kliping (surat kabar).htm.

HR, Syaukani. Menatap Harapan Masa Depan Otonomi Daerah. Kutai: Gerbang Dayaku.

Joeniarto, R. 1992. Perkembangan Pemerintah Lokal. Jakarta: Bumi Aksara.

Kansil, C.S.T. 1983. Sistem Pemerintahan Indonesia. Jakarta: Aksara Baru.

. 1986. Hukum Tata Negara Republik Indonesia. Jakarta: Bina Aksara.

Kusnardi, Moh. dan Harmaily Ibrahim. 1981. Hukum Tata Negara Indonesia. Jakarta: Pusat Studi Hukum Tata Negara FH UI dan CV. Sinar Bakti.

Lubis, Solly. 1983. Perkembangan Garis Politik dan Perundang-undangan Pemerintah Daerah. Bandung: alumni.

Manan, Bagir. 1994. Hubungan antara Pusat dan Daerah Berdasarkan Asas 
Desentralisasi Menurut UUD 1945. Jakarta: Pustaka Sinar Harapan.

2001. Menyongsong Fajar Otonomi Daerah. Yogyakarta: Pusat Studi Hukum FH UII.

Sarundajang. 2000. Arus Balik Kekuasaan Pusat ke Daerah. Jakarta: Pustaka Sinar Harapan.

Soehino. 1996. IImu Negara. Yogyakarta: Liberty.

Soejito, Irwan. 1990. Hubungan Pemerintah Pusat dan Pemerintah Daerah. Jakarta: Rineka Cipta.

Soemantri, Sri. 1981. Pengantar Perbandingan Hukum Tata Negara. Jakarta: Rajawali.

Strong, C.F.. 1966. Modern Political Constitution. London: The English Language Book Society and Sidgwick \& Jackson Limited.
Sugandhi, Dann. 1981. Masalah Otonomi dan Hubungan antara Pemerintah Pusat dan Daerah di Indonesia. Bandung: Sinar Baru.

Surbakti, Ramlan. "Otonomi Daerah Seluasluasnya dan Faktor Pendukungnya." $h t t p: / / w w w . o t d a . o r . i d /$ Artikel/Ramlan.htm.

The Liang Gie. 1993. Pertumbuhan Pemerintahan Daerah di Negara Republik Indonesia. Yogyakarta: Liberty.

Tim Lapera. 2000. Otonomi Versus Negara. Yogyakarta: Lapera.

Editorial Media Indonesia. "Bom Waktu Otonomi Daerah." 9 November 2000. http://www.otoda.or.id/artikel/ artikel11.htm. 